\title{
An avifaunal survey of the vanishing montane Atlantic forest of southern Bahia, Brazil
}

\author{
L. P. GONZAGA, J. F. PACHECO, C. BAUER and \\ G. D. A. CASTIGLIONI
}

\section{Summary}

Recent ornithological surveys of humid forest remnants in the Serra da Ouricana near Boa Nova, southern Bahia, Brazil, revealed the existence of an as yet unnoticed montane Atlantic forest avifauna. Among the 220 species recorded, 27 represent range extensions of several hundred kilometres, several others were preceded only by single or a few old, disputed records from Bahia, and at least two are undescribed taxa. A portion of this avifauna has been recorded in other mountainous areas of interior Bahia (Chapada Diamantina, plateau of Maracás), where a complex vegetation mosaic that includes patches of humid forest is found.

In addition to the two undescribed passerines, nine other threatened and thirteen near-threatened species have been recorded in the study area. Considered together with the adjoining and also highly endangered "mata-de-cipó", forest habitats in the Boa Nova area are probably the most neglected habitats in Brazil concerning bird conservation.

Levantamentos ornitológicos recentemente feitos em remanescentes florestais úmidos na Serra da Ouricana perto de Boa Nova, sul da Bahia, Brasil, revelaram a existência nessa região de uma avifauna montícola da mata Atlântica. Entre as 220 espécies registradas, estão 27 que tiveram sua área de distribuição estendida por centenas de quilômetros, muitas outras conhecidas da Bahia apenas através de registros antigos e contestados, além de ao menos duas aves não descritas. Parte dessa avifauna foi também registrada em outras áreas montanhosas do interior da Bahia (Chapada Diamantina, Chapadão Maracás), onde se encontra um complexo mosaico de vegetação que inclui manchas de floresta úmida. Além dos dois pássaros não descritos, outras nove espécies ameaçadas e treze quase-ameaçadas foram registradas na área de estudo. Considerando-se em conjunto essa área com a vizinha "mata-de-cipó", também muito ameaçada, pode-se dizer que os ambientes florestais na região de Boa Nova são os hábitats mais negligenciados em relação à conservação de aves no Brasil.

\section{Introduction}

The relatively well explored mountainous region of the states of Rio de Janeiro, Espirito Santo and eastern Minas Gerais has been taken as the northern limit of distribution of many Brazilian Atlantic forest endemic birds. This has been substantiated by the contribution of several workers since early in this century 
(e.g. Holt 1928, Davis 1945, Pinto 1954, Scott and Brooke 1985, Pacheco et al. 1992, Sick 1993), but it has also, in several instances, been obscured by $A$. Ruschi's misleading publications on the birds of Espírito Santo (Pacheco et al. 1993). Many of the species in question range south through São Paulo and Paraná to north-eastern Argentina and eastern Paraguay; while they often occur at or near sea-level in the coastal lowlands to the south, in the northern parts of their ranges they are usually restricted to mountains (see Sick 1993).

The concentration of endemic species in the montane forests of south-eastern Brazil was noted by Scott and Brooke (1985), who calculated that the proportion of endemics in the avifauna increased steadily from sea-level to 1,200 $\mathrm{m}$, above which elevation about $50 \%$ of the species occurring in their study areas were endemic to the Atlantic forest. Even in the north-east, from northern Espírito Santo north to Ceará, the affinities of lowland birds are primarily with the Amazonian avifauna, while at even moderate elevations a distinct composition is to be found. For example, the avifauna of the region of Murici (c. $500 \mathrm{~m}$ above sea-level) in the state of Alagoas includes endemic taxa related to south-eastern birds, and species that extend from the serras of the south-east and there reach their northern limit of distribution (Teixeira 1987a).

Although the state of Bahia has been cited as the northern distributional limit of numerous birds of the Atlantic forest, many of these records have been subject to question owing to the lack of modern evidence from this region. Most of the surveyed areas of Atlantic forest in Bahia lie on the once extensively forested coastal tablelands to foothills from the "Recôncavo" of Salvador southwards (see Pinto 1935, 1943, Gonzaga et al. 1987). The most important surveys of birds from the interior of Bahia, including its mountainous region and drier areas, were those undertaken by Wied (1820-1821) and, early in this century, by Emil Kaempfer, whose collections have only partially been studied, chiefly by Naumburg (1928, 1935, 1937, 1939).

It has apparently not hitherto been realized, however, that montane Atlantic forest exists in Bahia, and that this may have been the source of many of the old, disputed bird records from the state. Indeed, it may be the source of novelties in the present. Following recent discoveries by D. Willis (verbally 1992) and other birdwatchers in the vicinity of Boa Nova (see Forrester 1993), we took advantage of a planned trip to this locality to look for and survey remaining patches of Atlantic forest in the region. What we found confirmed our initial suspicion that a very important area existed there that had gone virtually unnoticed by earlier workers: tiny remnants of a formerly extensive forest that occurred in this central-southern portion of Bahia along the Serra da Ouricana (point A in Figure 1). The humid forest on the seaward slopes of this ridge delineates both the westernmost and the highest elevational limits of the Atlantic forest domain in the region. Just a few kilometres to the west, this forest gives way to the "mata-de-cipó," best known to ornithologists for its endemic genus Rhopornis (see Collar et al. 1992: 679).

Here we report on our 1992/1993 surveys of Atlantic forest birds near Boa Nova, provide a preliminary reassessment of the ornithogeography of central-southern Bahia, and point out the implications for conservation in this region. 


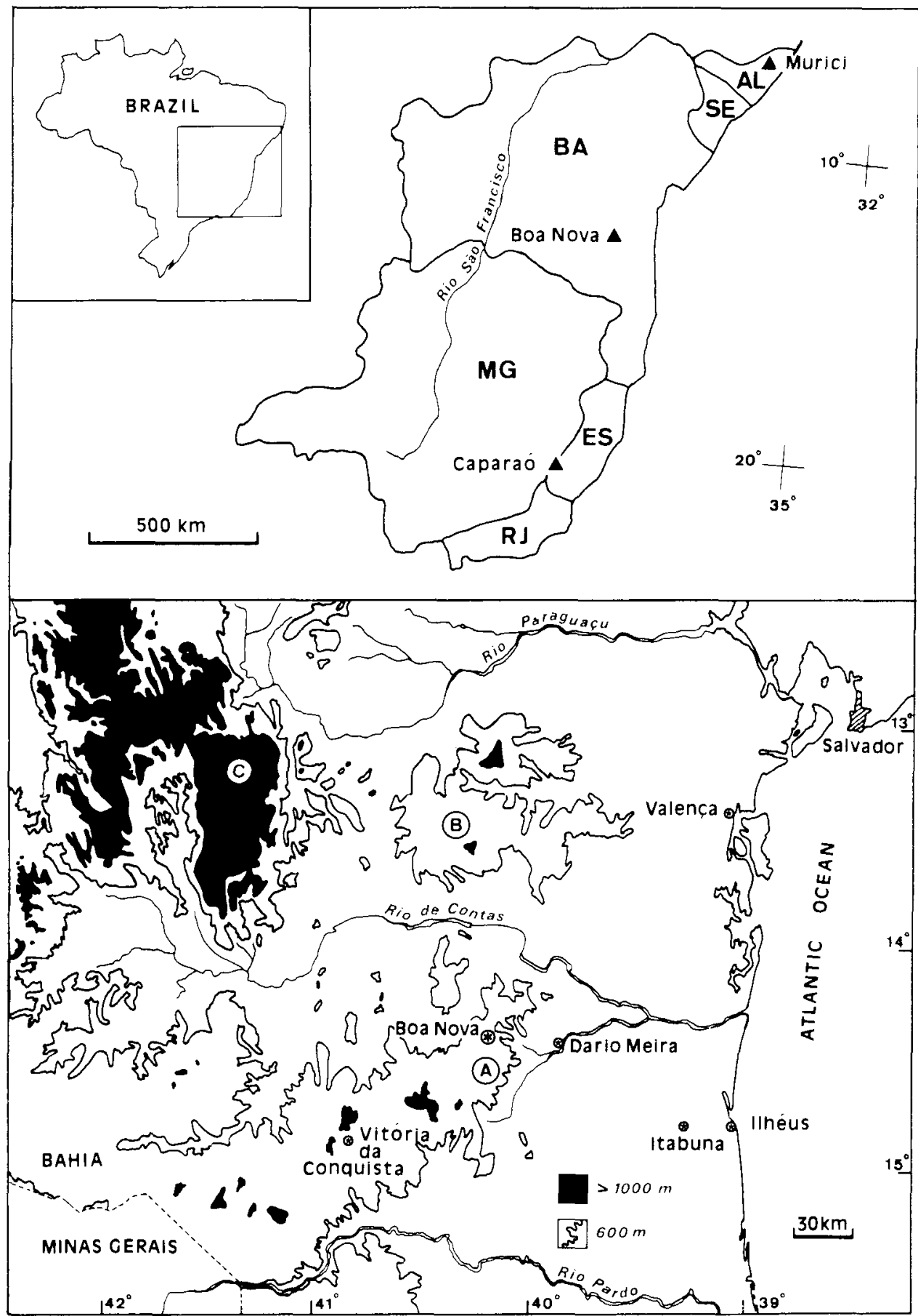

Figure 1. Map showing localities mentioned in text. (A) Serra da Ouricana; (B) Plateau of Maracás; (C) Serra do Sincorá (Chapada Diamantina National Park). 


\section{Study area and methods}

Ornithological surveys of the Atlantic forest patches around Boa Nova were undertaken in three locations. One (site 1) was along a trail that crossed a very disturbed and possibly old secondary patch of forest near the summit of the mountain $(900-1,100 \mathrm{~m}) 7 \mathrm{~km}$ south-east of the town. This track, which led directly down to the main road to Dario Meira, was reported by local people to have been used for heart-of-palm exploitation in the recent past. The second (site 2 ) is a tract of forest reaching lower elevations $(750-1,000 \mathrm{~m}$ ) in the same range c. $13 \mathrm{~km}$ south-east of Boa Nova by the same road, and crossed by an equally good trail (see Forrester 1993). These two sites were visited between 30 August and 6 September 1992 and from 24 to 28 August 1993 (in this period with P. S. M. da Fonseca).

We found another, more extensive (c.30o ha) patch of similar forest (site 3) in much better condition in the vicinity of site 2 during our expedition in 1993, but due to difficulties of access only a very brief visit could be made. This site (as well as site 2) was revisited in November 1993 by J.F.P. and B. Whitney.

Surveys were conducted mainly by walking through the forest trails and along edges, and recording birds seen and/or heard. In addition, a few mist-nets were used at site 1 in August 1993. Elevations were determined with a Thommen altimeter. Recordings of bird voices were made with Uher 4000 Report- $\mathrm{L}$ and Sony TCM-50oo tape-recorders and are deposited at the Arquivo Sonoro Elias Coelho (ASEC) in the Universidade Federal do Rio de Janeiro. A few specimens were collected and prepared as skins for further study and documentation. Comparisons of these were made with those in the ornithological collection of the Museu de Zoologia da Universidade de São Paulo.

\section{Results and discussion}

\section{The montane avifauna of central-southern Bahia}

The avifauna at the surveyed sites near Boa Nova comprises a montane element heretofore known mainly from the serras in Espírito Santo and Rio de Janeiro southwards, combined with an element from the extreme north-east in Alagoas (Table 1). This list includes: (a) birds that are strictly montane throughout their ranges (e.g. Mouse-coloured Tapaculo Scytalopus speluncae); (b) birds strictly or principally montane in the northern limits of their ranges in eastern Brazil that may occur regularly at or near sea-level in the coastal lowlands to the south (e.g. Tufted Antshrike Mackenziaena severa); (c) birds strictly montane in eastern Brazil that may be widespread in lowlands elsewhere (Wing-barred Manakin Piprites chloris); (d) birds apparently restricted to mountains in southern Bahia that may be widespread in lowlands elsewhere (Lemon-chested Greenlet Hylophilus thoracicus); (e) birds known only from montane forests in southern Bahia (e.g. Bahia Tyrannulet Phylloscartes sp.).

The most emphatically montane forest bird whose occurrence in Bahia has been generally admitted is the Rufous-brown Solitaire Myadestes leucogenys. This might have provided a clue to the existence of a true montane bird fauna in southern Bahia that previously had been overlooked. However, the only 
Table 1. Montane birds recorded in the study area near Boa Nova". Taxonomy follows Sick (1993) with the exception of Aratinga auricapilla following Ridgely (1981), and Chamaeza spp. following Willis (1992).

\begin{tabular}{|c|c|}
\hline Crupturellus obsoletus ${ }^{* b} \mathrm{~V}$ & Phyllomyias burmeisteri ${ }^{*} \mathrm{v}$ \\
\hline Leucopternis polionota $\mathrm{I}$ & Phyllomyias griseocapilla ${ }^{* 1} \mathrm{v}$ \\
\hline Columba plumbea $1 \mathrm{Dv}$ & Phylloscartes oustaleti ${ }^{*}+$ \\
\hline Aratinga auricapilla $\mathrm{Dv}$ & Phylloscartes sp. ${ }^{*} \mathrm{v}+$ \\
\hline Pyrrhura frontalis $1 \mathrm{DV}$ & Hemitricass diops o1v \\
\hline Pionopsitta pileata o $\mathrm{v}$ & Hemitriccus furcatus ${ }^{*} 4 \mathrm{~V}$ \\
\hline Pionus maximiliani & Todirostrum poliocephalum o1v \\
\hline Phaethornis eurynome ${ }^{*} \mathrm{~V}+$ & Todirostrum plumbeiceps ${ }^{*} \mathrm{DV}$ \\
\hline Melanotrochilus fuscus & Contopus cinereus $1 \mathrm{DV}$ \\
\hline Aphantochroa cirrhochloris o1v & Colonia colonus IDV \\
\hline Clytolaema rubricauda ${ }^{*} \mathrm{v}$ & Muscipipra vetula ${ }^{\mathrm{d}}$ \\
\hline Trogon surracura Dv & Sirystes sibilator on $\mathrm{Dv}$ \\
\hline Scytalopus speluncae ${ }^{*} \mathrm{~V}+$ & Chiroxiphia caldata orv \\
\hline Scytalopus indigoticus ov + & licura militaris ${ }^{* \mathrm{~d}} 1 \mathrm{v}$ \\
\hline Hypoedaleus guttatus IV & Schiffornis iirescens o1v \\
\hline Mackentiaena severa ${ }^{*} 1 \mathrm{v}$ & Laniisoma elegans o \\
\hline Thamnophilus caerulescens ${ }^{*}{ }_{1} \mathrm{Dv}+$ & Phibalura flavirostris ${ }_{5} \mathrm{D}$ \\
\hline Dysithammus stictothorax o1v & Iodopleura pipra ${ }^{*} \mathrm{v}$ \\
\hline Dysithammus mentalis $1 \mathrm{v}$ & Lipangus lanioides ${ }^{*} \mathrm{v}$ \\
\hline Drymophila ferruginea $\mathrm{I}^{\mathrm{e}} \mathrm{v}$ & Pyroderus scutatus DV \\
\hline Drymophila ochropyga ${ }^{*} \mathrm{Dv}+$ & Procnias nudicollis $\mathrm{ID}$ \\
\hline Cercomacra brasiliana ${ }_{1,2 \mathrm{~V}}$ & Piprites chloris ${ }^{*} \mathrm{~V}$ \\
\hline Myrmeciza loricata $\mathrm{xDV}$ & Oxyruncus cristatus iv \\
\hline Chamaeza campanisona ov & Myadestes leucogenys \\
\hline Chamaeza meruloides ov & Platycichla flavipes oD \\
\hline Conopophaga lineata $\mathrm{IDv}$ & Hylophilus thoracicus ${ }^{* b \cdot d} \mathrm{v}$ \\
\hline Synallaxis spixi ${ }_{1} \mathrm{Dv}$ & Basiletuterus culicizorus ox DV \\
\hline Synallaxis sp. ${ }^{* \mathrm{f}} \mathrm{v}+$ & Hemithraupis ruficapilla $\mathrm{o}^{\mathrm{j}} \mathrm{1 \textrm {v }}$ \\
\hline Cranioletuca pallida $\mathrm{o}^{\mathrm{g}} \mathrm{v}+$ & Trichothraupis melanops o1v \\
\hline Anabazenops fuscus ${ }^{*} 1 \mathrm{v}+$ & Thraupis cyanoptera ${ }^{*} \mathrm{v}$ \\
\hline Philydor lichtensteini ${ }^{* 3}{ }_{1}+$ & Thraupis ornata 1 \\
\hline Philytor nufus o1 & Pipraeidea melanonota o \\
\hline Cichlocolaptes lencophrys ov & Chlorophonia cyanea ov \\
\hline Lochmias nematura ${ }_{1}{ }_{1} \mathrm{VV}$ & Tangara cyanocephala o \\
\hline Sittasomus griseicapillus ${ }^{\mathrm{h}} \mathrm{I} \mathrm{DV}$ & Tangara cyanoventris $\mathrm{IDV}$ \\
\hline Lepidocolaptes s. squamatus $1 \mathrm{DV}$ & Pitylus fuliginosus ov \\
\hline Campylorhamphus falcularius $1,3 \mathrm{~V}$ & Saltator similis ID \\
\hline
\end{tabular}

All species except Procnias nudicollis have been recorded in this survey; additional sources are as follows: 1. Forrester (1993); 2. Collar et al. (1992); 3. Teixeira et al. (1993); 4. F. Lambert (in litt. 1993); 5. P. Snetsinger (verbally 1993). " Recorded by Whitney (1988) near Itatingui. " Recorded by Gonzaga et al. (1987) at CVRD Porto Seguro Reserve. 'Recorded by Souza (1990) from Bahia (no specified locality). "Record by Teixeira et al. (1989) from Valença as the first from Bahia was preceded by Naumburg's (1939) from Jequié. 'Probably this species has been erroneously taken as Synallaxis ruficapilln by others (see Forrester 1993). ${ }^{8}$ Recorded by T. S. Schulenberg (in litt. 1995) and others near Jequié. ${ }^{h}$ Probably S. g. olivaceus. ' Record by Souza (1990) was based on a misidentification of Myiopagis caniceps from Chapada Diamantina by J.F.P. ' Probably H. r. ruficeps.

*, birds recently recorded in the study area for the first time from Bahia according to published records;

o, birds recorded in the study area for which no specific localities in Bahia were mentioned in the literature, or recorded only by Wied (1820-1821);

D, birds recorded also in the Chapada Diamantina by R. Parrini (verbally 1994) or J.F.P. and P. S. M. da Fonseca;

v, voice(s) recorded by L.P.G., J.F.P., B. Whitney or P. S. M. da Fonseca;

+ , specimen(s) collected. 
published locality record of this species was Itabuna (Pinto 1944), elevation $<200 \mathrm{~m}$, which is nearer to the coast and has an avifauna typical of lowland Atlantic forest. The record from Itabuna, in the winter (Pinto 1944), could thus have represented an altitudinal migrant from nearby uplands. More recently, the Rufous-brown Solitaire was recorded in the coastal hills $(400 \mathrm{~m})$ near Itatingui, south of Itabuna, in the summer (Whitney 1988).

Montane Atlantic forest birds are known also in the Maracás region (e.g. at Jaguaquara: see Naumburg 1935, 1939) and in the very central portion of Bahia along the Chapada Diamantina, where the highest points in the state, Pico das Almas $(1,836 \mathrm{~m})$ and Pico do Barbado $(2,033 \mathrm{~m})$, are situated. Noteworthy examples are Reddish-bellied Parakeet Pyrrhura frontalis, Bare-throated Bellbird Procnias nudicollis and Gilt-edged Tanager Tangara cyanoventris, all recorded from Senhor do Bonfim (Pinto 1938, 1944) in the extreme north of this range. In this region, patches of deciduous and semi-deciduous forest, savanna and caatinga form a complex vegetation mosaic. The existence of moister forest enclaves at higher elevations surrounded by drier vegetation has long been recognized in north-eastern Brazil. Several such enclaves are present in central Bahia; floristic surveys of these areas, locally called "brejos", have revealed the occurrence of several plant species known also from the Atlantic forest region of south-eastern Brazil (de Andrade-Lima 1982).

It is noteworthy that at site 1 , at about $1,000 \mathrm{~m}$, we collected a harvestman Currala bahiensis B.Soares, 1972 (Opiliones: Gonyleptidae) and a frog Hyla novaisi Bokermann, 1968 (Amphibia: Hylidae) that were described from the plateau of Maracás, at an elevation of about $1,350 \mathrm{~m}$, nearly $100 \mathrm{~km}$ north-west of Boa Nova. The harvestman belongs in a subfamily which is distributed mainly in forest along the coast south of Bahia from eastern Minas Gerais, Espirito Santo and Rio de Janeiro to Santa Catarina, and was known only from the type-locality (A. Kury verbally 1994). The frog was considered at the time of its description to be closely allied to $H$. senicula from Rio de Janeiro (Bokermann 1968), and has been found also at Pedra Azul, northern Minas Gerais (M. Gomes verbally 1994).

Among the 220 species recorded in the study area (excluding those elements of the adjoining "mata-de-cipó"), 27 represent significant range extensions into Bahia state (Table 1 ). Boa Nova is almost $700 \mathrm{~km}$ away from the nearest patches of montane Atlantic forest (in Caparaó and other serras of Espírito Santo), where most of these species were previously known to occur, and half-way between those and forests in Alagoas to the north-east, where some of them also occur (Figure 1). Despite this, we were not surprised at the occurrence of these species in Bahia, and believe that habitat alteration in the Serra da Ouricana (see Conservation) has resulted in local extinctions of some others that have not been found.

Several species recently recorded at Boa Nova, while they do not represent range extensions to Bahia, were known then only from single or a few nineteenth century records (e.g. trade skins shipped to European museums from "Bahia" with no specified localities, and those of Wied 1820-1821). Some of these, such as those typical of the serras in Espírito Santo and Rio de Janeiro, including White-breasted Tapaculo Scytalopus indigoticus, Swallow-tailed Manakin Chiroxiphia caudata and Greenish Manakin Schiffornis virescens, could 
have been (and some indeed have been) queried as odd old records due to a still-incomplete understanding of the ornithogeography of Bahia. Others (Amethyst Woodstar Calliphlox amethystina, Three-striped Flycatcher Conopias trivirgata and White-necked Thrush Turdus albicollis crotopezus) probably are not chiefly mountain birds in the region.

One of the remaining challenges represented among these old records is that of the possible continued existence in this region of the White-winged Potoo Nyctibius leucopterus, described by Wied (1820-1821) from Fazenda da Preguiça, near Vitória da Conquista. Although we paid particular attention to the possibility of finding this bird in our study area, in our limited evening efforts we recorded only the Long-tailed Potoo $N$. aethereus. It is worth mentioning that Wied (1820-1821) reported having found both species in the same forests at the type locality of the former. Despite the statement in Collar et al. (1992:681) that the source of the type of White-winged Potoo was the dry forest near Vitória da Conquista, it is at least equally possible that it occurred or still occurs in this adjoining area of Atlantic montane forest. A potoo, considered to be this species, has recently been found in Amazônia near Manaus (Cohn-Haft 1993), but possibly only its rediscovery somewhere near the type-locality will completely clarify the taxonomic status of the Amazonian population.

We failed to record any bristlefront, either Stresemann's Merulaxis stresemanni, known from only two specimens taken near Salvador and Ilhéus, or Slaty $M$. ater, known from the serras of the south-east. A prediction could be made of a greater probability of occurrence of the latter, bearing in mind the possibility that Stresemann's Bristlefront (like perhaps the Bahia Tapaculo Scytalopus psychopompus: see below) is restricted to the coastal tablelands (see Collar et al. 1992). Although on several occasions we used a recorded song of Slaty Bristlefront for playback in apparently suitable habitat, no response was obtained.

Although the Hooded Berryeater Carpornis cucullatus has been recorded as an "accidental" (a single undocumented record) at Boa Nova by Forrester (1993), we met only with Black-headed Berryeater $C$. melanocephalus, which is apparently uncommon at site 3. In Espírito Santo, the northern documented limit of its range, and in Rio de Janeiro, Hooded Berryeater is restricted to mountains, usually above $400 \mathrm{~m}$, while Black-headed Berryeater is usually found in lowlands, including in southern Bahia (Sick 1993, pers. obs.). This represents an apparent case of altitudinal parapatry (see Haffer 1992). In Alagoas, where Hooded Berryeater does not occur, Black-headed Berryeater was recorded in the highlands (about $550 \mathrm{~m}$; Teixeira et al. 1986), although it may have been overlooked in lower altitude forests there.

Apparently other species follow this pattern of altitudinal replacement in eastern Brazil. The mutually exclusive distributions of Screaming Piha Lipaugus vociferans and Cinnamon-vented Piha L. lanioides, discussed by Snow (1982), might be another example. Nevertheless, given that both have extensive ranges outside the area of overlap (from about Rio de Janeiro to Bahia), and that $L$. lanioides does not descend to the lowlands and $L$. vociferans does not go above about $500 \mathrm{~m}$, the complementary ranges in eastern Brazil are not apparently due to interactions between these species (D. Stotz in litt. 1995).

Another species whose distribution parallels that of the Black-headed Berryeater is the Scaled Antbird Drymophila squamata. Due to differences in 
habitat, however, it seems unlikely that the elevational distribution of this bird is affected by the presence or absence of other species of Drymophila. The Scaled Antbird was recorded as the only representative of its genus in the highlands of Alagoas (Teixeira et al. 1986) but is more of a lowland bird in the south-east, where up to four other species of Drymophila may occur together in certain mountain ranges (Willis 1988, Sick 1993, D. Stotz in litt. 1995). In southern Bahia, Scaled Antbird extends from the lowlands (Pinto 1938) to above $800 \mathrm{~m}$ in "Ituaçu" (Naumburg 1939; probably Itiruçu in the plateau of Maracás, see Collar et al. 1992: 680, Remarks 2) and Boa Nova (pers. obs.). In our study area, only two other species of Drymophila have been recorded, the Ferruginous Antbird D. ferruginea and Ochre-rumped Antbird D. ochropyga, both chiefly montane birds in Espírito Santo and Rio de Janeiro.

\section{Taxonomic challenges}

A spinetail Synallaxis sp. (Pacheco and Gonzaga in prep.) and a tyrannulet Phylloscartes sp. (Gonzaga and Pacheco in press) that we collected and tape-recorded in the study area proved to be undescribed, geographically very isolated, taxa. The spinetail forms a clear link in both morphological and vocal characters between Rufous-capped S. ruficapilla from the south-east and Plain $S$. infuscata from the north-east. The tyrannulet belongs in a group that includes Mottle-cheeked Tyrannulet $P$. $v$. ventralis from the south-east and Long-tailed Tyrannulet $P$. ceciliae from the north-east. The Variable Antshrike Thamnophilus caerulescens found in these forests is closest in plumage coloration to the north-eastern subspecies pernambucensis/cearensis, but a further bioacoustic investigation of this complex is needed.

A local population of Scale-throated Hermit Phaethornis eurynome found at site 1 possesses a very distinct song type, although in a preliminary analysis it apparently does not differ morphologically from its southern sisters. As Vielliard (1983) reported a great amount of individual - but apparently not populational - variation, possibly associated with learning, in the song of this species near the southern end of its range, it may be that a dialect has arisen in this northern, isolated population. This certainly would constitute an interesting topic for further study; see also Snow (1968) and Wiley (1971) for a discussion of song variation in another species of this genus.

In light of the occurrence of both White-breasted and Mouse-coloured Tapaculos at Boa Nova, the taxonomic status of the recently described (Teixeira and Carnevalli 1989) Bahia Tapaculo S. psychopompus must be reviewed. This bird has been recorded at only two localities, Valença and Ilhéus (Collar et al. 1992). As Boa Nova is situated just between these two sites, albeit at a higher elevation and farther inland, we have carefully considered the possibility of birds found there being referable to $S$. psychopompus. All tapaculos recorded, however, instead matched either White-breasted or Mouse-coloured in size, plumage coloration, and vocal repertoire (see Vielliard 1990). In the south-east, White-breasted Tapaculo occurs from sea-level (very locally) to at least $1,500 \mathrm{~m}$, and Mouse-coloured Tapaculo is restricted to higher elevations, but there is overlap between about $800 \mathrm{~m}$ (Boracéia in São Paulo) and 1,500 $\mathrm{m}$ in certain ranges (Sick 1993, B. Whitney verbally 1994, D. Stotz in litt. 1995). 
Knowledge of the voices of tapaculos, especially those of the genus Scytalopus, is often essential for an understanding of their taxonomic relationships (e.g. Fjeldså and Krabbe 1990, Vielliard 1990, Whitney 1994). Vuilleumier et al. (1992) have tentatively listed psychopompus as an allospecies of the S. indigoticus superspecies but, in the absence of knowledge about the voice of the Bahia Tapaculo, an evaluation of its taxonomic status cannot properly be made.

\section{Conservation}

From the evidence presented here, it is clear that a true, highly localized, montane forest avifauna exists in central-southern Bahia. Unfortunately, however, Atlantic forest has virtually disappeared from the mountain tops and lower slopes of the Serra da Ouricana around Boa Nova owing to the expansion of pastureland and cultivation. All the sites we visited were privately owned and under pressure from clearance and fire spreading from neighbouring cleared areas. Furthermore, they were almost certainly the only remnants of Atlantic forest in the region, as we could judge from observations made from elevated look-outs, interviews with local people, and exploration in search of other forest patches. This situation, coupled with the very limited size of these fragments, gives cause for special concern. Finding a suitable area for creation of a conservation unit of this habitat and its birds at equivalent altitudes in southern Bahia is, therefore, an urgent need.

Since the Slender Antbird Rhopornis ardesiaca was rediscovered near Boa Nova (Naumburg 1934), most subsequent work by ornithologists at this locality has apparently been directed exclusively or mainly towards locating and studying this bird in the "mata-de-cipó" (e.g. Willis and Oniki 1981, Teixeira 1987b), and the existence of Atlantic forest a few kilometres to the east has thus remained unnoticed. Curiously enough, however, even after this area had been discovered by other workers (see Introduction), no one explicitly pointed out its singularity and relevance (see, e.g., Collar et al. 1992: 680, Remarks 3, and Forrester 1993).

Nine species included as threatened in Collar et al. (1992) have been recorded in the study area: Golden-capped Parakeet Aratinga auricapilla, Blue-chested Parakeet Pyrrhura cruentata, Golden-tailed Parrotlet Touit surda, Striated Softtail Thripophaga macroura, Shrike-like Cotinga Laniisoma elegans, Black-headed Berryeater Carpornis melanocephalus, Buff-throated Purpletuft Iodopleura pipra, Cinnamon-vented Piha Lipaugus lanioides, and Fork-tailed Pygmy-tyrant Hemitriccus furcatus. The two new endemic suboscines (see "Taxonomic challenges" above), found too late to have been considered for inclusion in the Red Data Book, are clearly threatened species that should be added to this list. In addition, thirteen "near-threatened" species (sensu Collar et al. 1992) also have been recorded there (Table 2).

The above figures alone indicate the magnitude of conservation concern that Serra da Ouricana deserves. Its plight can be paralleled in the Atlantic forest region perhaps only by that of highland forests in Alagoas where, however, some conservation measures are now beginning (Collar et al. 1992: 602, 630). Small and vulnerable as the forests in Alagoas may be, they have not been subjected to the dire circumstances surrounding the continued existence of the 
Table 2. Near-threatened birds (sensi Collar et al. 1992) recorded in the study area near Boa Nova. Taxonomy follows Sick (1993).

Mantled Hawk Leucopternis polionota

Blue-winged Macaw Propyrhura maracana

Pileated Parrot Pionopsitta pileata

Spot-breasted Antvireo Dysithammus stictothorax

Ochre-rumped Antbird Drymophila ochropyga

Rio de Janeiro Antbird Cercomacra brasiliana

Grey-capped Tyrannulet Phyllomyias griseocapilla

Oustalet's Tyrannulet Phylloscartes oustaleti

Shear-tailed Grey-tyrant Muscipipra retula

Swallow-tailed Cotinga Phibalura flavirostris

Bare-throated Bellbird Procnias nudicollis

Rufous-brown Solitaire Myadestes lencogenys

Azure-shouldered Tanager Thraupis cyanoptera

montane forests of southern Bahia. Considered together with the adjoining and also highly endangered "mata-de-cipó" (which harbours a distinctly different avifauna that includes several endemic and threatened birds: see Collar et al. 1992: 680) forest habitats in the Boa Nova area are, in terms of bird conservation, probably the most neglected habitats in Brazil.

\section{Acknowledgements}

We would like to express our appreciation of Bret M. Whitney and Paulo Sérgio M. da Fonseca for their valuable help and companionship throughout. We are grateful to Dave Willis, Paul Gadd and Ricardo Parrini for making available to us information on their bird surveys of Bahia, Thomas Schulenberg for providing us with a copy of a recording of the Amazonian White-winged Potoo, and Adriano Kury, Marcia dos Reis Gomes, Oswaldo L. Peixoto and Richard Sachsse for the identification and additional information provided on the harvestmen and frogs of Atlantic forest. Douglas Stotz and Helio F. de A. Camargo kindly allowed us to examine specimens in MZUSP. B. Whitney and D. Stotz made valuable contributions to the manuscript. C.B. and G.D.A.C. benefitted from fellowships provided respectively by Conselho Nacional de Desenvolvimento Científico e Tecnológico (CNPq) and Coordenação de Aperfeiçoamento de Pessoal de Nível Superior (CAPES). Support to ASEC came from CNPq and the Fundação Universitária José Bonifácio.

\section{References}

de Andrade-Lima, D. (1982) Present-day forest refuges in northeastern Brazil. Pp.245251 in G. T. Prance, ed. Biological diversification in the tropics. New York: Columbia University Press.

Bokermann, W. C. A. (1968) Three new Hyla from the plateau of Maracás, Central Bahia, Brazil. J. Herpetology 1: 25-31.

Cohn-Haft, M. (1993) Rediscovery of the White-winged Potoo (Nyctibius leucopterus). Auk 110: 391-394. 
Collar, N. J., Gonzaga, L. P., Krabbe, N., Madroño Nieto, A., Naranjo, L. G., Parker, T. A., III, and Wege, D. (1992) Threatened birds of the Americas: the ICBP/IUCN Red Data Book. Cambridge, U.K.: International Council for Bird Preservation.

Davis, D. E. (1945) The annual cycle of plants, mosquitoes, birds and mammals in two Brazilian forests. Ecol. Monogr. 15: 243-295.

Fjeldså, J. and Krabbe, N. (1990) Birds of the high Andes. Copenhagen: Zoological Museum, University of Copenhagen, and Svenborg: Apollo Books.

Forrester, B. C. (1993) Birding Brazil: a check-list and site guide. Irvine: John Geddes.

Gonzaga, L. P. and Pacheco, J. F. (in press) A new species of Phylloscartes (Tyrannidae) from the mountains of southern Bahia, Brazil. Bull. Brit. Om. Club.

Gonzaga, L. P., Scott, D. A. and Collar, N. J. (1987) The status and birds of some forest fragments in eastern Brazil: report on a survey supported by CVRD, October 1986. Unpublished.

Haffer, J. (1992) Parapatric species of birds. Bull. Brit. Orn. Club 112: 250-264.

Holt, E. G. (1928) An ornithological survey of the serra do Itatiaya, Brazil. Bull. Amer. Mus. Nat. Hist. 57: 251-326.

Naumburg, E. M. B. (1928) Remarks on Kaempfer's collections in eastern Brazil. Auk 45: $60-65$.

Naumburg, E. M. B. (1934) Rediscovery of Rhopornis ardesiaca (Wied). Auk 51: 493-496.

Naumburg, E. M. B. (1935) Gazetteer and maps showing stations visited by Emil Kaempfer in eastern Brazil and Paraguay. Bull. Amer. Mus. Nat. Hist. 68: 449-469.

Naumburg, E. M. B. (1937) Studies of birds from eastern Brazil and Paraguay, based on a collection made by Emil Kaempfer. Bull. Amer. Mus. Nat. Hist. 74: 139-205.

Naumburg, E. M. B. (1939) Studies of birds from eastern Brazil and Paraguay, based on a collection made by Emil Kaempfer. Bull. Amer. Mus. Nat. Hist. 76: $231-276$.

Pacheco, J. F., Carvalho, C. E. S. and da Fonseca, P. S. M. (1992) Notas sobre a ocorrência e distribuição de algumas espécies [de aves] no Parque Estadual do Desengano, norte do Estado do Rio de Janeiro. R.11 in Resumos, II Congresso Brasileiro de Ornitologia. Campo Grande: Universidade Federal de Mato Grosso do Sul.

Pacheco, J. F., Parrini, R. and Carvalho, C. E. S. (1993) A lista das aves do Espírito Santo a partir de uma análise crítica sobre os trabalhos de Augusto Ruschi. R.21 in Resumos, III Congresso Brasileiro de Ornitologia. Pelotas: Universidade Católica de Pelotas.

Pinto, O. M. de O. (1935) Aves da Bahia. Revta. Mus. Paulista 19: $x-325$.

Pinto, O. M. de O. (1938) Catálogo das aves do Brasil e lista dos exemplares que as representam no Museu Paulista. Revta. Mus. Paulista 22.

Pinto, O. M. de O. (1943) Nova contribuição à ornitologia do Recôncavo (Baía). Pap. Azuls. Dep. Zool. São Paulo 3: 265-284.

Pinto, O. M. de O. (1944) Catálogo das aves do Brasil. 2a. Parte. São Paulo: Departamento de Zoologia.

Pinto, O. M. de O. (1954) Aves do Itatiaia. Lista remissiva e novas achegas à avifauna da região. Bol. Parq. Nac. Itatiaia no. 3.

Ridgely, R. S. (1981) The current distribution and status of mainland Neotropical parrots. Pp.233-384 in R. F. Pasquier, ed. Conservation of New World parrots. Washington, D.C.: Smithsonian Institution Press for the International Council for Bird Preservation (Techn. Publ. 1).

Scott, D. A. and Brooke, M. de L. (1985) The endangered avifauna of southeastern Brazil: a report on the BOU/WWF expeditions of $1980 / 81$ and $1981 / 82$. Pp.115-139 in A. W. Diamond and T. E. Lovejoy, eds. Conservation of tropical forest birds. Cambridge, U.K.: International Council for Bird Preservation (Techn. Publ. 4).

Sick, H. (1993) Birds in Brazil: a natural history. Princeton: Princeton University Press.

Snow, D. W. (1968) The singing assemblies of Little Hermits. Living Bird 7: 47-55.

Snow, D. W. (1982) The cotingas. London: British Museum (Natural History). 
Souza, D. G. S. (1990) Lista das aves do Estado da Bahia. Unpublished report.

Teixeira, D. M. (1987a) A new tyrannulet (Phylloscartes) from northeastern Brazil. Bull. Brit. Orn. Club. 107: 37-41.

Teixeira, D. M. (1987b) Notas sobre o "gravatazeiro", Rhopomis ardesiaca (Wied, 1831). Revta. Bras. Biol. 47: 409-414.

Teixeira, D. M. and Carnevalli, N. (1989) Nova espécie de Scytalopus Gould, 1837, do nordeste do Brasil. Bol. Mus. Nac. Rio de Janeiro, n.s.Zool. no. 331.

Teixeira, D. M., Nacinovic, J. B. and Tavares, M. S. (1986) Notes on birds of northeastern Brazil. Bull. Brit. Orn. Club. 106: 70-74.

Teixeira, D. M., Nacinovic, J. B. and Luigi, G. (1989) Notes on some birds of northeastern Brazil (4). Bull. Brit. Orn. Club. 1o9: 152-157.

Teixeira, D. M., Otoch, R., Luigi, G., Raposo, M. A. and de Almeida, A. C. C. (1993) Notes on some birds of northeastern Brazil (5). Bull. Brit. Orn. Club. 113: 48-52.

Vielliard, J. (1983) Catálogo sonográfico dos cantos e piados dos beija-flores do Brasil, 1. Bol. Mus. Biol. Prof. Mello-Leitão, sér. biol. no. 58.

Vielliard, J. (1990) Estudo bioacústico das aves do Brasil: o gênero Scytalopus. Ararajuba 1: $5-18$.

Vuilleumier, F., LeCroy, M. and Mayr, E. (1992) New species of birds described from 1981 to 1990. Bull. Brit. Orn. Club. 112A: 267-309.

Whitney, B. M. (1988) Birds recorded above Itatingui, Bahia, 26 January 1988. Unpublished report.

Whitney, B. M. (1994) A new Scytalopus tapaculo (Rhinocryptidae) from Bolivia, with notes on other Bolivian members of the genus and the magellanicus complex. Wilson Bull. 106: 585-614.

Wied [-Neuwied], M. Prinz zu (1820-1821) Reise nach Brasilien in den Jahren 1815 bis 1817 . Frankfurt [am Main]: Heinrich Ludwig Broenner.

Wiley, R. H. (1971) Song groups in a singing assembly of Little Hermits. Condor 73: 28-35. Willis, E. O. (1988) Drymophila rubricollis (Bertoni, 1901) is a valid species (Aves, Formicariidae). Revta. Bras. Biol. 48: 431-438.

Willis, E. O. (1992) Three Chamaeza antthrushes in eastern Brazil (Formicariidae). Condor 94: $110-116$.

Willis, E. O. and Oniki, Y. (1981) Notes on the Slender Antbird. Wilson Bull. 93: 103107.

L. P. GONZAgA, J. F. PACHECO, C. BAUER and G. D. A. CASTiglioni

Departamento de Zoologia, Universidade Federal do Rio de Janeiro, Caixa Postal 68033, 21944-97o Rio de Janeiro, RJ, Brazil. 